\title{
Human Rights City Initiatives as a Peoples Peace Process
}

\author{
Jackie Smith, ${ }^{1}$ University of Pittsburgh
}

Chapter in: People's Peace Processes. Edited by Yasmin Saikia and Chad Haines. Syracuse University Press. (pages 181-201)

Pre-production copy

Much peace research focuses on government-led, top-down interventions aimed at ending violent conflict. Less attention is devoted to the ways civil society groups help prevent conflicts from escalating into violence by promoting values and practices that foster social justice and peace. The Human Rights City initiative is an example of how popular groups are organizing to advance policies and support values and practices that nurture human rights and peace. Since the 1990s, activists around the world have been developing this model for addressing economic inequality, discrimination, and other root causes of conflict. This chapter examines the work of residents of Pittsburgh (including the author) to advance human rights in that city, which became the $5^{\text {th }}$ human rights city in the United States in 2011. It considers how Human Rights Cities' work to advance "dignity and justice for all residents" serves as a model for building a peoples' peace that can reduce violence and foster justice in communities.

This consideration of "peoples peace" processes begins with a critique of some of the prevailing approaches in the peace research literature that have limited its ability to advance understandings of peace and knowledge of how to reduce violence. These dominant approaches start with the implicit assumption that peace agreements must operate within the existing, highly militarized interstate order. In doing so, these approaches privilege top-down approaches to peace building where the national state is central to peace processes. Furthermore, they reinforce existing centers and margins, reproduce "market epistemologies" (Da Costa and McMichael 2007), and neglect the world-historical context in which states and societies are embedded.

In contrast to conventional, state-centric approaches, world-historical perspectives situate the modern state in the context of the capitalist world-system, which is based on competition for resources that reproduces inequality, exploitation, and violence (Wallerstein 2004). Such inequities and violence — and the wars and "state failures" they produce — are reproduced by an interstate system in which states have no choice but to compete in an increasingly globalized 
economy. Yet, virtually all postwar peace-building agreements require that states emerging from wars enact economic policies aimed at (re-)integrating that state into the world economy-such as trade liberalization, privatization, and reduced government regulation and spending-despite the association between these policies and the underlying causes of violent conflict (Uvin 2002; Paris 2003; Kamola 2007). In short, there is a strong case to be made that the structural violence produced by the capitalist world-system is a major contributor to militarized conflicts and other forms of physical violence in the modern world (see, e.g., Sassen 1998; Harvey 2009; 2003; Smith 2010). Thus, to be effective, peace-building strategies - whether local or global — cannot avoid the need to transform the structures of the capitalist world-system.

A second critique of existing literature is its tendency to privilege states and other elite actors as the main protagonists in peace processes, despite the fact that most analyses of peace building conclude that civil-society actors play vital roles in the processes of postwar peace building. Among the tasks civil society actors perform are intermediation and facilitation between citizens and the state, advocacy for marginalized groups, monitoring for accountability, socialization for a culture of peace, and fostering social cohesion (Paffenholz and Spurk 2006; 2010; Paffenholz 2010). Clearly these functions are at the core of building peace in any society, and they are common features of what this volume's contributors are calling people's peace. It should go without saying, however, that in most post-war contexts civil society actors are left weakened and relatively powerless to engage in these tasks that are so essential to achieving a de-escalation of violence and a return to some semblance of peace. This is particularly so in cases where war and militarized conflict have produced physical dislocations and devastation as well as heightened social polarization. Moreover, even where conflicting parties are not engaged in violence, institutional arrangements are not likely to be very supportive of, and may even hinder, civil society's performance of these critical tasks (see, e.g., Lang 2013). Thus, peace researchers and practitioners should devote far more attention to a wide range of people's peace processes - that is, the ongoing work of social movements that contributes to these kinds of peace-building-related activities in nonwar contexts in all parts of the world-not only the Global South (Smith et al. 2013:207). The aim of this work should be not only to document people's peace processes and make them part of the larger framework of discussions about peace building, but also to identify the practices and policies needed to support civil society actors in their critical peace-building functions of helping people realize their own "emancipation from a 
world economic system based in inequality and violence" (Smith and Verdeja 2013:12).

Inevitably, support for people's peace projects and the civil-society peace builders who advance them will run counter to the interests of privileged political actors.

\section{The Human Rights Cities Movement}

An important example of a people's peace project is the human rights cities movement which includes a variety of local initiatives aimed at achieving peoples" "right to the city" — that is, implementing international human rights norms into local contexts. Such initiatives have been proliferating around the world since the 1990s. The formal "Human Rights Cities" initiative was launched by the Peoples Decade for Human Rights Education (PDHRE) in the wake of the 1993 World Conference on Human Rights in Vienna. The initiative aims to mobilize people in communities to "pursue a community-wide dialogue and launch actions to improve the life and security of women, men and children based on human rights norms and standards" (Marks et al. 2008:45). The process of becoming a Human Rights City (HRC) can vary, and some communities start with a City Council resolution designating the city a HRC. In other contexts, organizers work to build broad community alliances to support human rights principles before seeking a formal Human Rights City designation. The key point is the intention of using human rights as a framework for community governance and the active engagement of popular groups in support of this aim.

Rosario, Argentina, became the first Human Rights City in 1997, motivated by residents' desires to prevent another military dictatorship and to reduce overall violence and social exclusion. Since then, activists around the world have been developing this model for transforming policymaking and raising public consciousness (Marks et al. 2008). The idea of Human Rights Cities has been spread by PDHRE through a variety of mechanisms, including at the World Social Forums, where tens of thousands of social justice organizers have gathered on an annual or biannual basis since 2001 (see Smith and Karides et al. 2014). Currently there are more than two dozen HRCs around the world, with growing numbers in the United States. ${ }^{2}$

Recognizing that prevailing social policies have done little to effectively address social problems such as poverty and social exclusion, human rights cities advocates contend that this initiative helps mobilize civil society actors in support of a policy agenda that promotes peace and social justice. The Human Rights City initiative 
encourages local communities to take charge of their own future by understanding their needs and the causes of the various forms of deprivation. ... Where local government is ineffective, corrupt, or non-existent and few opportunities are available to mobilize beyond the family and clan, a human rights cities initiative is a vehicle for raising awareness and transforming that awareness into action for social change. (Marks et al. 2008:18)

Beyond providing a model for local organizing, the HRC initiative is also valuable for its ability to connect local communities with a global movement and to offer a rich body of international human rights law that validates and reinforces local claims. The value of such international connection cannot be underestimated for its role in motivating community engagement, providing guidance and models for local action, and gaining attention from policy makers and other elites in the community. PDHRE's examination of the impacts of HRC organizing in cities around the world led to the conclusion that

[t]hose who have participated in the creation of Human Rights Cities have acquired a skill set and confidence for questioning those power relations that make deprivation of human rights possible. They use the legal and administrative systems to their advantage and address problems of urban poverty as participants in change rather than victims of fatality or recipients of charity. ... The idea that social and economic injustice is "the way the world is" yields to awareness that people can change their condition by civic engagement for societal development based on human rights. (Marks et al. 2008: 146147)

By remedying the significant failures of top-down and state-centered approaches to peace building, this people's peace approach supports fundamental changes in local communities that are necessary for a durable and just peace.

Pittsburgh's Human Rights City Alliance 
Pittsburgh officially became the fifth HRC in the United States in April of 2011, when high school students working in the local American Friends Service Committee's Racial Justice through Human Rights Program proposed the initiative to the Pittsburgh City Council. Following the passage of the Human Rights City Proclamation, however, there was no organized follow-up by activists to implement the Proclamation until activists, including this author, came together to plan a rally for International Human Rights Day in 2013. Organizers recognized an opportunity in the recent election of a mayor who had been a City Councilman when the HRC Proclamation was passed.

The core leadership of the Human Rights City Alliance in its early phase came from several faculty members and graduate students at the University of Pittsburgh (including this author), the American Friends Service Committee, whose youth group made Pittsburgh a HRC, and a handful of activists from some of the main social and racial justice groups in the city. ${ }^{3} \mathrm{We}$ recognized early on, following social movements in other places, that work for human rights

needs to begin with a focus on those who are least able to enjoy their rights. ${ }^{4}$ Yet, these very same people have the most difficulty attending meetings and otherwise participating in the work of the HRC Alliance and other activist groups. Knowing that racial, generational, and other differences and tensions have long complicated efforts to build movements in the United States, we sought to learn from past experiences and to be intentional about our aim of building a multiracial and multiclass alliance for human rights. ${ }^{5}$ We thus spent our first year learning about issues most critical to low-income and African American residents and developing relationships with leading organizers on these issues. We sought guidance from leaders in those communities and worked to sensitize more privileged residents to the ways prevailing institutions and practices deny many people their basic human rights and dignity. We built a steering committee for the Alliance with the intention of having a majority leadership from historically oppressed groups.

\section{Expanding the Political Imagination}

We live in a society in which the inalienable rights to private property and the profit rate trump any other conception of inalienable rights you can think of. This is so because our 
society is dominated by the accumulation of capital through market exchange.... We must imagine a more inclusive, even if continuously fractious, city based not only upon a different ordering of rights but upon different political-economic practices (Harvey 2003:940-941)

By calling people to imagine how our city could look if it were organized around the goal of promoting universal human rights, it became clear that we were inviting them to imagine a very different place. Participants quickly recognized that we needed to change the mindsets of politicians and the public, accustomed to thinking of local politics as mainly about parties and elections and policies aimed at attracting businesses to the city while avoiding tax increases. Very quickly people could see (if they didn't already) that the privileging of economic growth in public policy meant that human rights would always be neglected. In addition, the human rights lens clarified how economic growth systematically undermines the ability of some groups in the city — in Pittsburgh this is especially African Americans and immigrants - to enjoy even the most basic rights. ${ }^{6}$ From here, we invited residents to consider not just different policies but also new practices and institutions that could better accomplish the aims of our "Human Rights City."

With this invitation, HRC initiatives are invoking creative social and political leadership from people and communities. One observer highlighted this sort of translation work in Washington D.C.:

One DC is working towards empowering residents, empowering the community in the Shaw and the District to know and claim their rights. It is this work that begins to make DC a human rights city, as organizing working-class and low-income communities of color and helping them build the power necessary to claim and protect their own rights is at the core of what human rights mean. ${ }^{7}$

What is also worth noting is that helping people know and embrace their full range of human rights reinforces their understanding of the indivisibility of economic and civil/political rights, thereby reducing the likelihood that the initiative will be co-opted by defenders of the status quo. It also leads to critical reflection on the overarching principles and values around which we build our society. Such reflection opens space for considering and imagining radically different 
alternatives. For example, Sacajawea Hall, a climate justice organizer who is part of Jackson Mississippi's HRC initiative, articulates the idea of a "people-centered human rights," which encompasses a system-level antiviolence emphasis that is essential to building a culture of peace: A people's centered human rights framework grows out of what oppressed people define for ourselves based on our struggles and goes beyond the limits of international legal text, it confronts white supremacy, settler-colonial capitalism, patriarchy and other systems of oppression that deny us our human agency and dignity. This framework is grounded in the understanding that we can only realize our full human rights when we change social relationships, structures and institutions.... We have to put forth our people-centered human rights framework, link it with the emerging Rights of Mother Earth Framework and the concept of "buen vivir" (roughly translated as "living well together") and reclaim our agency, social space, and the right to live in harmony with each other and our provider and sustainer, Mother Earth. (Hall 2015, emphasis added)

Here we see the emphasis on redefining the basic relations of society in ways that confront and challenge the current order based in the violence of colonialism, patriarchy, and racism. By naming the violence of this social order and creating spaces where residents can reflect on and work to reshape social relations, projects like the HRCs address systemic/structural violence and enable true peace building to occur. Moreover, we're seeing in contemporary social movements an effort to connect human rights with environmental justice, or rather to force people to confront and transform the violent nature of humans' relationship with the Earth. The ideas of buen vivir and Rights for Mother Earth expressed above are clearly integral to the realization of human rights, yet they are also fundamentally incompatible with the existing world-system.

By creating spaces where residents can share their visions and discuss concrete strategies, HRCs invite participants to expand their political imaginations. In doing so it challenges the prevailing political culture, which relies on passive and uncritical citizenship, organized within the electoral framework of elite-controlled political parties and the goals they define. Of course, the prevailing mindsets and socialization in the dominant political culture also make it difficult for many people to imagine social change happening outside the formal, top-down government policy framework. This same culture also complicates the work of mobilizing and sustaining 
large numbers of volunteers for the long, hard work aimed at transforming the basic structures of society from the bottom-up (see, e.g., Eliasoph 2011).

The key point here is that peace building requires work to disrupt and transform our current political and economic system to one based on principles of cooperation, inclusion, and human rights. Much of the work of peace building, then, must focus on changing peoples' consciousness and their understandings about community priorities, values and governance. HRCs work to change the script of politics to make human rights a priority, and HRC leaders are effectively working to "translate" principles from the global arena for local audiences. This has enabled our group and other HRC initiatives to mobilize people from a diverse array of backgrounds around a collective project that helps overcome the demographic segregation and issue silos that plague conventional organizing. As Merry observes,

Human rights translators work ... within the constraints of existing discursive fields whose complex and multivocal messages are open to various, and uncontrollable, interpretations. Human rights intermediaries put global human rights ideas into familiar symbolic terms and use stories of local indignities and violations to give life and power to global movements. They hold a double consciousness, combining both transnational human rights concepts and local ways of thinking about grievances. (2006:42)

The realization of the principles and ideals in international human rights law is not an automatic process or one that can be dictated from above. It requires intentional interventions of people and processes to engage diverse local populations in the shared work of building a just and peaceful society.

It is also important to note how countries involved in internal or external wars - including the United States —often insulate themselves from discussions about international law and norms. In the United States, American exceptionalism can also limit the resonance of human rights as an organizing framework. For instance, Finnegan et al. (2010) interviewed organizers in more than 40 activist groups in Boston about their views of human rights as an organizing framework. They found that only a third was actively using human rights frames in their organizing. In our work in Pittsburgh, we're also finding that human rights is not 
immediately resonant in many segments of the activist community. Yet, human rights language does have resonance, and it has proved effective at illuminating intersections among different struggles and nurturing local solidarities. Its international orientation encourages people to consider how their concerns transcend local and national politics and to see common identities with people engaged in similar struggles elsewhere. Perhaps for this reason, respondents to the Boston study above noted that many of their staff relied on human rights frameworks in their thinking, and a third of the groups they interviewed were beginning to move toward greater use of human rights language. Most of their respondents felt human rights are an effective tool for local organizing, despite the unique political and cultural constraints in the United States. Thus, the work of human rights translators is clearly a critical element of people's peace processes, particularly in settings where politics and violent conflict actively obstruct the values of social inclusion, peace, and justice.

The HRC model, then, has been useful for creating links between our local community and global movements and ideals. For instance, HRCs have helped translate global human rights principles into local settings in their work to promote awareness of the Universal Declaration of Human Rights and other human rights treaties. For some participants in the United States, the opportunity to read (often for the first time) the Universal Declaration of Human Rights and to confront the gap between its principles and the experiences of people in their community is jarring. ${ }^{8}$ Projects such as the monitoring of international human rights treaties such as the Convention on the Elimination of all forms of Racial Discrimination, ${ }^{9}$ and the introduction of local legislation to implement global treaties such as the "Cities for CEDAW" initiative, ${ }^{10}$ are common elements of HRCs. And annual celebrations of International Human Rights day reinforce people's understandings of the history and universality of human rights.

Because using human rights as a framework for governance entails a paradigm change, we're finding in the HRC initiative in Pittsburgh that a big part of our work involves disrupting dominant ways of thinking and acting. At this early phase of our work, we spend a good deal of effort working with community leaders to encourage them to consider how a human rights framework might advance their group's goals. We're also working to raise greater awareness about the ways different groups - such as African Americans, immigrants, LGBT residents - are denied many basic rights. In our outreach, we're working against an often competitive non-profit culture that leads many organizers to be suspicious of our motives. We're essentially working to 
change culture as much as policy; our work must take place at many levels - from policy arenas to schools and neighborhoods, to interpersonal and interorganizational relations.

My participatory research on HRCs has helped illuminate the basic tasks that HRCs do. I outline some of these tasks and illustrate how HRCs implement these in Table 1. These functions mirror those that have been associated with civil society's peace-building roles, For instance, HRCs empower residents to monitor public policies and practices and to press for change where policies don't meet human rights standards, with projects such as Washington D.C.'s annual Human Rights Report Card. They work to foster a human rights culture to challenge the mainstream culture based in consumerism, individualism, and economic growth. And they create public spaces where diverse residents can come together to engage in dialogue, learn about each other's experiences, and build commitment to shared principles and projects. By simply calling residents together to envision and build a HRC, organizers mobilize residents around a shared public vision, thereby strengthening local democracy and creating an essential foundation for lasting peace.

Table 1: Human Rights Cities \& the Functions of Peacebuilding

\begin{tabular}{|c|c|}
\hline Functions & $\begin{array}{l}\text { Actual HRC projects (in Pittsburgh and } \\
\text { elsewhere) }\end{array}$ \\
\hline $\begin{array}{l}\text { Advocacy for Marginalized Groups } \\
\text { Mobilizing and legitimating demands for } \\
\text { social inclusion }\end{array}$ & $\begin{array}{l}\text { * Monitoring local-level compliance with international } \\
\text { treaties such as CERD } \\
\text { *Pressing for local adoption of international treaties like } \\
\text { CEDAW, CRC } \\
\text { *Building and strengthening community relationships/ } \\
\text { diverse alliances supporting human rights } \\
\text { *Drafting and enacting Human Rights City Action Plan }\end{array}$ \\
\hline $\begin{array}{l}\text { Holding public officials accountable to } \\
\text { human rights values. }\end{array}$ & $\begin{array}{l}\text { *Referencing human rights criteria in appeals to } \\
\text { policymakers on a variety of issues. } \\
\text { *"Welcome to our Human Rights City" open letters to new } \\
\text { public officials } \\
\text { *Relating local demands to national and international human } \\
\text { rights norms/laws, regardless of their formal ratification } \\
\text { status. } \\
\text { *Appealing to HRC status to advocate for and justify pro- } \\
\text { human rights initiatives. }\end{array}$ \\
\hline $\begin{array}{l}\text { Socialization for a Culture of Peace } \\
\text { Expanding the public space where the } \\
\text { 'common good' can be discussed, } \\
\text { imagined, and defined by diverse groups } \\
\text { of residents. } \\
\text { Fostering mutual understandings and } \\
\text { sensitivities to inequalities and power } \\
\text { dynamics. }\end{array}$ & $\begin{array}{l}\text { *Creating spaces for public deliberation. } \\
\text { *Public events on Human Rights Day-identifying changes } \\
\text { needed to realize human rights } \\
\text { * Organizing events that enable dialogues about human rights } \\
\text { and their implications for policy. } \\
\text { *Helping residents understand the intersections of various } \\
\text { issues and demands; reframing diverse aims in terms of } \\
\text { human rights. }\end{array}$ \\
\hline
\end{tabular}




\begin{tabular}{|c|c|}
\hline $\begin{array}{l}\text { Building engaged citizenry and participatory } \\
\text { models of governance - vs. passive } \\
\text { citizenship and leadership by 'experts.' }\end{array}$ & $\begin{array}{l}\text { *Building community task force to research public policies } \\
\text { and recommend strategies for improving human rights } \\
\text { outcomes; } \\
\text { *Engaging residents in monitoring human rights practices; } \\
\text { *Inviting and facilitating actions to hold public officials } \\
\text { accountable to human rights. }\end{array}$ \\
\hline \multirow[t]{2}{*}{$\begin{array}{l}\text { Fostering Social Cohesion } \\
\text { Encouraging popular engagement in shared } \\
\text { projects to envision and build a better } \\
\text { society } \\
\text { Public consciousness-raising and human } \\
\text { rights education }\end{array}$} & $\begin{array}{l}\text { *Building networks among diverse community leaders } \\
\text { *Defining shared project for community coalitions. } \\
\text { *Building a "human rights culture," or "making human } \\
\text { rights a way of life" in the community. } \\
\text { *Human Rights training for youth and adults, community } \\
\text { leaders, public officials, and police. }\end{array}$ \\
\hline & $\begin{array}{l}\text { *Human Rights Curriculum for schools } \\
\text { *Cultural work- e.g., film festivals, essay contests, music } \\
\text { group... }\end{array}$ \\
\hline
\end{tabular}

${ }^{\S} \mathrm{CERD}=$ Convention on the Elimination of all forms of Racial Discrimination; CEDAW=Convention on the Elimination of All forms of Discrimination Against Women; $\mathrm{CRC}=$ Convention on the Rights of the Child

In what follows, I provide some examples of the work of our HRC Alliance that advance peacebuilding functions in our community. Specifically, I look at advocacy for marginalized groups, fostering social cohesion, and advancing socialization for a culture of peace.

\section{Advocacy for Marginalized Groups/ Fostering Social Cohesion}

Capitalism relies upon its ability to exploit differences and inequalities among groups of people in order to maximize profits for the owners of capital. Thus, the globalized capitalist system has generated institutions that reproduce and expand inequalities and reinforce divisions and hierarchies in society, inhibiting communication and cooperation across differences. As a result, we're finding in our HRC work that even decisions about when, where, and how we hold our meetings are very political and that work to be inclusive of diverse groups - especially those most impacted by rights violations - takes conscious planning and investment of resources to make it work. But we also have found that, by creating spaces where people who do not ordinarily come together can meet, our alliance is fulfilling an important need in our racially and class-divided city. Indeed, democracy depends on public deliberation among all members of a community, and such deliberation has been inhibited by prevailing practices and institutions and by pervasive inequalities. So the work we're doing strengthens both democracy and social cohesion. Moreover, by helping residents gain awareness of global human rights law and movements, we translate lessons from international peace building into local settings. Our one- 
on-one work with community leaders and volunteers also contributes to building the relationships that nurture the values and practices of a democratic culture.

The most important public actions the HRC Alliance organizes are public forums where participants can learn about human rights and the diverse experiences and perceptions of human rights as seen by other residents. Examples of this are our International Human Rights Day $\underline{\text { rallies }^{11}}$ and a panel we organized to honor International Mother Earth Day. ${ }^{12}$ These events were designed to bring the voices of the most marginalized groups to the fore so that we could reflect collectively on the challenges and opportunities for advancing "dignity and justice for everyone." We also have worked to ensure that youth voices are heard in these spaces, aiming to both nurture young leaders while also helping older folks appreciate the needs and challenges faced by our city's youth. It is clear in these meetings that more privileged participants are challenged by hearing the accounts of experiences of people denied their rights due to their race, class, gender, citizenship status, or ability. But our work to facilitate ongoing conversations and relationships among different organizations, leaders, and constituencies has helped sustain and build participation and support for the HRC initiative. This work has benefitted from previous efforts of residents to fight racial injustice and division, which include an annual "Summit Against Racism" where we are able to organize panels, identify allies, and build networks to support the HRC initiative and its racial justice component in particular (see our 2015 and 2016 reports $\left.\frac{13}{}\right)$.

Our most recent work around Human Rights Day led us to an innovation of holding Human Rights Days of Action ${ }^{14}$ rather than organizing just a single event to mark this day. This enabled us to reach out to a wider range of groups and encourage them to link their own work to a human rights framework. In turn, we helped publicize their human rights-related events to a larger audience. In this way we were able to expand the numbers of people working to frame their demands in terms of human rights as well as to enhance peoples' awareness of the intersectionalities among movements.

In addition to holding public forums, we have also worked to support mobilizations against police brutality and racial discrimination. In the fall of 2014, Pittsburgh's mayor appointed a new police chief, whom we welcomed to the city in October with an open letter ${ }^{15}$. The key point of the letter was to make sure our new chief was aware of Pittsburgh's status as a Human Rights City. Moreover, we wanted to offer community support for human rights-oriented 
policing practices, and members of our group engaged in research to learn more about the recommendations from other cities and from the United Nations in this regard. Later that fall we joined the local Amnesty International chapter during their annual Human Rights Day letterwriting action to issue a letter to the police chief ${ }^{16}$ raising specific human rights demands that had been identified by local groups working specifically on police accountability.

In addition to these activities, we spent much of the first year of our HRC Alliance learning about the work being done in the community and speaking with community groups and leaders about their policy priorities and visions. This work informed our Human Rights City Action Plan, ${ }^{17}$ which we made public at our 2014 International Human Rights Day rally. The Action Plan identifies some demands and changes essential to moving us closer to being a true Human Rights City, such as universal health care, eliminating racial disparities, and living wage laws. It is intended as a blueprint to guide policymakers and local organizers, and it has inspired the creation of new task forces of volunteers working to implement specific components of the plan. As we continue to build, we're working to deepen connections between human rights organizers and area universities, and in the summer of 2015 we organized a workshop to bring together activists and scholars from within and beyond Pittsburgh to examine the lessons and possibilities of Human Rights Cities (Human Rights City Alliance 2015).

These actions illustrate how the HRC Alliance has supported the work of diverse organizations and leaders and build understanding and trust among groups that don't ordinarily work together. Such understanding and trust, and the networks of relationships behind this, are critical to nurturing shared identities and social cohesion. Moreover, in doing this work, it has become even clearer to me that peace building requires conscious efforts to mobilize people in ways that counter the competitive and exclusionary nature of the prevailing social order and institutions. Because our people-centered human rights framework privileges voices of those marginalized by the existing institutions, it helps sensitize participants to power dynamics and exclusion, enabling group trust and cohesion to develop. The process of organizing towards a "human rights city" - more than any single event or action — unifies participants around a shared project and set of principles that builds and deepens social relationships.

This is not to say that the process has been easy. We remain a rather small network of committed organizers, and our work still consists largely of learning about the human rightsrelated work and concerns of diverse community residents, meeting with different community 
leaders to build relationships, and supporting collaborative projects among area organizations. It requires patient and persistent efforts to demonstrate how uniting around human rights can strengthen the overall work for social justice in our city. Often we are seen as pushing just another issue and advancing the interests of our 'organization,' and we find ourselves working to transform prevailing activist mindsets. We frequently must stress that we are not attempting to be a new and distinct organization, but rather we are an alliance of like-minded groups that can support cooperative and coordinated efforts toward a shared vision for social change.

\section{Socialization for a Culture of Peace}

Our work to transform Pittsburgh into a Human Rights City has helped residents appreciate that human rights cannot simply be legislated. As HRC organizers have stressed, the goal is to make human rights a "way of life" for people in our region. This requires multiple kinds of activities in multiple places of social life. It encourages a transformation of values and priorities and people's understanding of 'the political' beyond conventional boundaries.

One initiative taken in Pittsburgh in this regard has been the support for recognizing Indigenous Peoples Day on October 12. The idea for this day first arose in 1977 at the International Conference on Discrimination Against Indigenous Populations in the Americas. ${ }^{18}$ In 2014, the Human Rights City of Seattle adopted a resolution renaming October 12 Indigenous Peoples Day in that city, explicitly linking the decision to that city's status as a HRC. One of our group members attended a rally organized by local activists honoring Indigenous Peoples Day in October of 2014, and he brought ideas from that rally to our meeting where we were planning that year's Human Rights Days activities. We drafted a text to submit to City Council based on Seattle's Resolution and that incorporated a demand made by local activists for "the teaching of Indigenous peoples' history as recommended by Indigenous communities in our public schools." The City Council of Pittsburgh passed a Will of the Council "recognizing the 12th of October as “Indigenous Peoples' Day"19 on the eve of Human Rights Day in 2014.

Work on this initiative conveys the importance of questioning the celebratory accounts of Christopher Columbus's encounter with the Americas and the subsequent European settlement of the place native peoples call Turtle Island. Pittsburgh does not have a large population of indigenous peoples given its history, and thus the voices of those displaced from this region are largely absent from this area's public discourse and consciousness. But the work of Indigenous 
social movements that have been calling for Indigenous Peoples Day and reflections of human rights organizers convinced us of the importance of "truth telling" about this country's imperialist, colonial, and genocidal history as a key first step in our work to nurture a human rights culture as we build a city that observes and protects human rights for all residents. As we know from studies of postwar societies, truth telling is essential to promoting healing and to realizing a culture of human rights. Thus, the transformation of consciousness and culture we are seeking with the HRC initiative requires that we tell new stories about our past so that we can imagine a different future that advances 'dignity and justice for everyone.' Toward that end, we are building a task force that is planning activities to collaborate with area Indigenous people's organizations to raise public consciousness as we honor the first officially recognized Indigenous People's Day in Pittsburgh.

The ongoing work of the Alliance is to continue to create spaces and support dialogues as well as cultural work that encourage residents to incorporate human rights into their everyday lives and thinking. With the help of our local Raging Grannies and some more youthful artists, our 2014 Human Rights Day rally was punctuated with human rights caroling, and activists shared lyrics that we hope will inspire more thinking and creative actions around human rights. We have also worked with labor groups to encourage a broader human rights framing of labor activism, and this effort is further supported by the rise of a movement of fast-food workers for a fifteen dollar minimum wage and the right to unionize. We have worked to support the city's annual May Day March for Immigrant Rights, led annually by local labor and immigrant rights organizations. In 2017, we helped lead work to sustain this multi-organization collaboration in support of immigrant rights beyond a single march by organizing a teach-in on the connections between the detention and deportation of immigrants and the larger prison industrial complex and the mass incarceration of African Americans and other people of color. In any case, by fostering more thinking and public discussion about human rights, this initiative contributes to a 'culture of peace' - that is, a respect for human rights and dignity, a commitment to community and to cooperative and peaceful approaches to addressing social conflicts, and greater awareness of those in the community (and beyond) who are excluded from the full enjoyment of human rights.

\section{Conclusion}


Attention to peoples' peace processes highlights the social processes through which values and practices that support peaceful social relations are generated and reproduced. Conventional, top-down approaches neglect these basic relations of society, as they begin with the interests and perspectives of elites who have little interest in addressing the structural sources of violence, even if they recognize these. The HRC initiative engages people in thinking about and working to realize bottom-up changes in institutions, practices, and culture that prioritize support and protection for human rights. This makes visible the claims of excluded groups and forces attention to underlying causes of inequality and discrimination. It does so by creating spaces where people can identify values relevant to peace that are present in their communities. It also helps communities come together to prioritize and defend such values, despite their marginalization by prevailing political and economic discourses. In Pittsburgh and other HRCs, it has created organizing processes aimed at incorporating human rights into public policy and the institutions of society. The orientation around advancing universal human rights - both economic social and cultural rights as well as civil and political rights - encourages attention to those groups that have been least able to enjoy such rights.

Significantly, this work runs counter to the prevailing social and political order. Analysts of globalization have demonstrated how neoliberal economic policies have undermined equality, democracy, and environmental sustainability everywhere-including the United States and other wealthy countries. Since democracy is typically understood as an essential tool for building peaceful communities, peace researchers must address the links between the organization of the global economy and its effects on the root causes of violence. Such work is not likely to be the project of elites, but rather of the people most impacted by violence. It is to those groups that we must look for leadership about the solutions to the pervasive and persistent violence in contemporary society.

The Human Rights City initiative offers an alternative, bottom-up approach for mobilizing people and groups around a unified framework that can challenge prevailing marketbased paradigms and policies that reproduce structural violence. We have found in Pittsburgh that it has appealed to diverse groups and that it has been especially helpful in fostering new dialogue and learning among people who have had difficulty coming together. As it does this, it encourages critical reflection and discussion of the operation of power and inequality in our 
community and has been a space where we actively confront questions about structural racism and how it is manifested in everyday practices and attitudes.

I'll end with a few observations about the role of people's peace projects like HRC initiatives in peace building and recommendations for how policy makers and analysts might better support this bottom-up peace-building work.

- Conventional peacebuilding models privilege states and actors that can threaten to disrupt 'peace' with violence. Because they are not seen as a threat, people's peace initiatives are often left out of peace negotiations, despite their centrality to constructing a durable peace founded on principles, practices, and a culture that is consistent with the values of peace and human rights. We must advocate for the inclusion of these initiatives in peace processes and ensure that peace agreements provide ample resources to support these kinds of peace-building initiatives in the aftermath of violent conflict.

- Dominant institutions tend to reproduce what Lang calls "institutional advocacy" that avoids conflict and contributes to the marginalization of less powerful groups. Conventional peace-building approaches focus on a few large, often well-funded players which are seen as organized voices of publics. In doing so these approaches neglect the voices of those most impacted by structural violence and 'hollow out the foundations of civil society' (Lang 2013:209). This work calls for attention to the work involved in building strong civil societies through public engagement and voice. Supporting groups that work to incubate engaged publics and support values of human rights and peace is essential to advancing a people's peace.

- Movement-building projects like the HRC initiative explored here are essential to the work of building a culture of peace. These projects tend to be coalitions of different groups with few independent resources or staff, and thus they often rely on the leadership of a few motivated individuals and volunteers. Yet, their work to foster dialogue and understanding across diverse groups and to build social cohesion and unity around shared projects is critical to promoting peace. Thus, efforts to better support such people's peace initiatives are needed.

- Strengthening international human rights can reinforce local human rights initiatives and related people's peace processes. At the same time, people's peace processes contribute 
to the strengthening of international human rights law, in what Mary Kaldor (2003) calls

a "double-boomerang" (see, e.g., MacNaughton and McGill 2012; Risse, Ropp, and

Sikkink 1999). Thus, we see how global peace processes can be enhanced by more attention to and support for local human rights work, and the local implementation of international human rights principles such as that described in this chapter, that helps actualize global rights norms in local settings.

\section{References}

Abro, James. 2014. "Poverty and Homelessness are Human and Civil Rights Issues" TalkPoverty.org October 9, 2014. At: http://talkpoverty.org/2014/10/09/poverty-andhomelessness/

Berends, Charlotte, Michelle Goossens, Maxime van Gerven, Lukas Hadtstein, Anneloes Hoff, Caroline Hamaker, and (Editors). "Human Rights Cities: Motivations, Mechanisms, Implications: A Case Study of European Human Rights Cities." University College Roosevelt. At: http://mensenrechten.verdus.nl/upload/documents/HRC-Book.pdf .

Center on Race and Social Problems. 2015. "Pittsburgh's Racial Demographics 2015: Differences and Disparities." University of Pittsburgh School of Social Work, Pittsburgh PA. At: http://www.crsp.pitt.edu/sites/default/files/Final\%20version\%20for\%20publishing.pdf.

Eliasoph, Nina. 2011. Making Volunteers: Civic Life after Welfare's End. Princeton, NJ: Princeton University Press.

Finnegan, Amy C., Adam P. Saltsman, and Shelley K. White. 2010. "Negotiating Politics and Culture: The Utility of Human Rights for Activist Organizing in the United States." Journal of Human Rights Practice 2:307-333.

Hall, Sacajawea. 2015. "Reflections on the People's Summit on Climate Change and our Climate Justice Movement." in Grassroots Global Justice Alliance Update. At: https://ggjalliance.wordpress.com/2015/01/15/reflections-on-the-peoples-summit-onclimate-change-and-our-climate-justice-movement/ Grassroots Global Justice Alliance.

Harvey, David. 2009. Social Justice and the City. Athens: University of Georgia Press.

Harvey, David. 2003. "The Right to the City." International Journal of Urban and Regional Research 27:939-941.

Human Rights City Alliance. 2015. "Making the Global Local: Human Rights CitiesConference Summary Report." At http://pghhumanrightscity.wikispaces.com/file/view/Conference\%20summary\%20General\%20Version\%203\%202.pdf/555558739/Conference\%20summary\%20General\%20Version\%203\%202.pdf.

Jain, Meetali. 2010. "Bringing Human Rights Home: The DC Right to Housing Campaign." Human Rights Brief 17:1-5. At: http://digitalcommons.wcl.american.edu/hrbrief/vol17/iss $3 / 2$

Kaldor, Mary. 2003. Global Civil Society: An Answer to War. Cambridge: Polity. Kamola, Isaac A. 2007. "The Global Coffee Economy and the Production of Genocide in Rwanda." Third World Quarterly 28:571-592. 
Lang, Sabine. 2013. NGOs, Civil Society, and the Public Sphere. New York: Cambridge University Press.

MacNaughton, Gillian and Mariah McGill. 2012. "Economic and Social Rights in the United States: Implementation Without Ratification." Northeastern University Law Journal 4:365-406.

Marks, Stephen P., Kathleen A. Modrowski, and Walther Lichem. 2008. Human Rights Cities: Civic Engagement for Societal Development. http://www.pdhre.org/Human_Rights_Cities_Book.pdf. New York: People's Movement for Human Rights Learning \& UN Habitat.

Merry, Sally Engle. 2006. "Transnational Human Rights and Local Activism: Mapping the Middle." American Anthropologist 108:38-51.

Meyer, Antoine. 2009. "Local Governments \& Human Rights Implementation: Taking Stock and a Closer Strategic Look." Pace diritti umani:7-25. At: http://mensenrechten.verdus.nl/upload/documents/MeyerPDU3_2009_A007.pdf

Paffenholz, Thania. 2010. "Civil Society and Peacebuilding." Pp. 43-64 in Civil Society and Peacebuilding: A Critical Assessment, edited by T. Paffenholz. Boulder, CO: Lynne Rienner Publishers.

Paffenholz, Thania and Christoph Spurk. 2010. "A Comprehensive Analytical Framework." Pp. 65-76 in Civil Society and Peacebuilding: A Critical Assessment, edited by T. Paffenholz. Boulder, CO: Lynne Rienner Publishers.

Paris, Roland. 2003. "Peacekeeping and the Constraints of Global Culture." European Journal of International Relations 9:441-473.

Risse, Thomas, Stephen C. Ropp, and Kathryn Sikkink. 1999. "The Power of Human Rights: International Norms and Domestic Change." New York: Cambridge University Press.

Sassen, Saskia. 1998. Globalization and its Discontents. New York: The New Press.

Smith, Jackie. 2010. "Globalization and Strategic Peacebuilding." Pp. 247-270 in Strategies of Peace: Transforming Conflict in a Violent World, edited by D. Philpott and G. F. Powers. New York: Oxford University Press.

Smith, Jackie, Marina Karides, Marc Becker, Dorval Brunelle, Christopher Chase-Dunn, Donatella della Porta, Rosalba Icaza, Jeffrey Juris, Lorenzo Mosca, Ellen Reese, Peter Jay Smith, and Rolando V'azquez. 2014. Global Democracy and the World Social Forums, 2nd Edition. Boulder, Colorado: Paradigm Publishers.

Smith, Jackie and Ernesto Verdeja, Eds. 2013. Globalization, Social Movements and Peacebuilding. Syracuse, NY: Syracuse University Press.

Smith, Jackie, Rebecca Burns, and Rachel Miller. 2013. "The World Social Forums as Transformative Peacebuilding." Pp. 207-234 in Globalization, Social Movements and Peacebuilding edited by J. Smith and E. Verdeja. Syracuse, NY: Syracuse University Press.

Uvin, Peter. 2002. "The Development/ Peacebuilding Nexus: A Typology and History of Changing Paradigms." Journal of Peacebuing and Development 1:5-24.

Wallerstein, Immanuel. 2004. World-Systems Analysis: An Introduction. Durham, N.C.: Duke University Press.

\section{End Notes}


${ }^{1}$ Jackie Smith is professor of sociology at the University of Pittsburgh and has long been active in local, national and international human rights organizing. She is co-founder of the International Network of Scholar-Activists and a co-founder and coordinator of the Human Rights City Alliance in Pittsburgh in addition to serving on the Steering Committee of the National Human Rights Cities Alliance.

${ }^{2}$ Washington D.C. became the first U.S. Human Rights City in 2008, followed by cities including Eugene, Oregon; Chapel Hill, North Carolina; Boston; Seattle; Pittsburgh, and most recently Jackson, Mississippi.

${ }^{3}$ The American Friends Service Committee has been instrumental in other human rights cities as well, including Washington D.C.'s.

${ }^{4}$ My research on the U.S. and World Social Forum process has informed this perspective, as these spaces are organized around a similar intentionality. The forces that have shaped the Social Forums include groups that have been involved in articulating new practices for building just and equitable multi-racial and multi-class alliances. For instance, on the Alliance's website, we refer to the Jemez Principles for democratic organizing as a guide to our work. And those helping guide our initiative drew from the wealth of resources of the U.S. Human Rights Network, which works for a "people-centered human rights movement" that centers its leadership on those most directly affected by human rights violations.

${ }^{5}$ Critical resources in this regard are the Jemez Principles for Democratic Organizing (http://www.ejnet.org/ej/jemez.pdf ), a set of principles developed by a multi-racial group of organizers convened by the Southwest Network for Environmental and Economic Justice in 1996, and the notion of a "People-Centered Human Rights Movement" expressed by the United States Human Rights Network (http://www.ushrnetwork.org/). ${ }^{6}$ Pittsburgh has among the highest rates of Black poverty, infant mortality, and unemployment in the country. The political marginalization of African Americans, moreover, has led to their significant displacement through ongoing processes of gentrification (Center on Race and Social Problems 2015).

${ }^{7}$ http://thedisorderofthings.com/2013/08/25/washington-dc-a-human-rights-city/

8 American exceptionalism also promotes the myth that the United States is a model or beacon of human rights, and so allowing for critical reflection on the reality of human rights in this country disrupts the myth of U.S. superiority which is used to help justify U.S. policies that undermine peace around the world.

${ }^{9}$ The U.S. Human Rights Network helps compile a "shadow report" to bring together evidence from communities around the U.S. to compare with the official U.S. report made under the CERD review process.

http://www.ushrnetwork.org/icerd-project

${ }^{10} \mathrm{http} / / /$ citiesforcedaw.org

${ }_{11}^{11} \mathrm{http} / / /$ pgh-humanrightscity.wikispaces.com/Event+Details

${ }^{12}$ http://pgh-

humanrightscity.wikispaces.com/file/view/Report\%20on\%20Mother\%20Earth\%20Day\%202014.pdf/507287904/Re port\%20on\%20Mother\%20Earth\%20Day\%202014.pdf

${ }^{13}$ Report on 2015 event: http://pghhumanrightscity.wikispaces.com/file/view/Summit\%20Against\%20Racism\%202015\%20REPORT\%20and\%20Age nda\%20Priorities.pdf/539653736/Summit\%20Against\%20Racism\%202015\%20REPORT\%20and\%20Agenda\%20P riorities.pdf ; Annual Report 2016: http://pgh-

humanrightscity.wikispaces.com/file/view/Annual\%20Report\%202016.pdf/603134886/Annual\%20Report\%202016. $\underline{\mathrm{pdf}}$

${ }^{14}$ http://pgh-

humanrightscity.wikispaces.com/file/view/Action\%20Calendar\%20One\%20Pager.pdf/533577676/Action\%20Calen dar\%200ne\%20Pager.pdf

${ }^{15}$ http://pgh-

humanrightscity.wikispaces.com/file/view/McLay\%20Letter\%20HRCA.pdf/528848990/McLay\%20Letter\%20HRC A.pdf

${ }^{16}$ http://pgh-humanrightscity.wikispaces.com/file/view/AI\%20Write-athon\%20Template\%20HR\%20Day\%202014.pdf/534797934/AI\%20Write-a-

thon\%20Template\%20HR\%20Day\%202014.pdf

${ }^{17} \mathrm{http} / / /$ pgh-humanrightscity.wikispaces.com/Human+Rights+City+Action+Plan

18 https://en.wikipedia.org/wiki/Indigenous_Peoples\%27_Day

${ }^{19} \mathrm{http://pgh-}$

humanrightscity.wikispaces.com/file/view/Indigenous\%20Peoples\%20Day\%20Will\%20of\%20the\%20Council.pdf/5 33004498/Indigenous\%20Peoples\%20Day\%20Will\%20of\%20the\%20Council.pdf 